\title{
The Role of Savings in Reducing the Effect of Oil Price Volatility for Sustainable Economic Growth in Oil Based Economies: The Case of GCC Countries
}

\author{
Ritab Al-Khouri ${ }^{1} \&$ Aruna Dhade ${ }^{1}$ \\ ${ }^{1}$ College of Business and Economics, Qatar University, Doha, Qatar \\ Correspondence: Ritab Al-Khouri, College of Business and Economics, Qatar University, Doha, Qatar. E-mail: \\ r.al-khouri@qu.edu.qa
}

Received: January 13, 2014

Accepted: February 11, 2014

Online Published: March 25, 2014

doi:10.5539/ijef.v6n4p172

URL: http://dx.doi.org/10.5539/ijef.v6n4p172

\begin{abstract}
We investigate the simultaneous links between oil price changes, national savings, legal and institutional development, and economic growth in the Gulf Cooperation Council (GCC) countries. Our study includes six GCC countries namely, Bahrain, Kuwait, Oman, Qatar, Saudi Arabia and the United Arab Emirates. We base our analysis on annual data that covers the period from 1980 to 2011. We implement different methodologies on time series cross sectional data: First, we test our model using fixed effect and random effect model techniques; Second, we employ Arellano-Bond/Blundell-Bond estimator to reduce the endogeneity problem that is common in this kind of studies. Results reveal a nonlinear and concave relationship between saving rates and economic growth. This result suggests that, at low level of economic growth, the increase in savings leads to high economic growth. However, as the countries' revenues and surpluses increase significantly (at higher levels in revenues and savings), high level of savings lead to lower growth in the economy. This might due to the lack of absorption capacity of the GCC markets. In addition, controlling for different factors, oil price changes explain the variability in the economic growth of the GCC countries. Economic globalization affects growth negatively, while institutional quality plays no role in economic growth of the GCC markets.
\end{abstract}

Keywords: oil price, savings, GDP per capita, economic openness

\section{Introduction}

\subsection{Oil Price Role in Economics Growth}

This research focuses on the simultaneous links between oil price changes, national savings, legal and institutional development, and economic growth in the GCC countries, by using two different econometric techniques and by controlling for the endogeneity problem, which prevails in this kind of studies. Our sample includes six GCC countries namely, Bahrain, Kuwait, Oman, Qatar, Saudi Arabia and the United Arab Emirates (UAE), over the time period 1980-2011 which includes oil shocks and adverse events such as the Iraqi invasion of Kuwait, as well as, the financial crisis.

Recently, it has been observed an increased interest in issues related to oil price movements and its effect on economic growth especially for oil exporting countries. Economically, these countries are highly integrated into the global economy and have a big impact on the world's largest economies that are dependent on oil. Therefore, the GCC countries are exposed to any movement in oil price, causing more volatility of their economic activity, and consequently uncertain economic growth. The oil price movement when positive offers an immense benefits to oil-exporting economies due to the increase in oil prices and production. The positive shocks lately caused a robust growth for the GCC economy which manifested itself in strong capital spending and economic growth. A series of political and financial crises in the last three decades, however, has apparent negative outcome of oil price fluctuations on economic development. The surplus in the current account balances easily promotes infrastructural investments and sustainable growth of GDP due to high level of savings. Though global oil price shocks are unexpected and unpredictable, therefore, causes a greater impact on endogenous economic variables for oil exporting economies depending mainly on oil revenues. Therefore, the high uncertainty in oil price movement, and consequently in oil revenues induce the GCC countries to save a large amount of their oil revenues for precautionary purposes. Policymakers in many oil-exporting countries especially GCC countries 
have to confront the question of how much to spend and how much to save given the highly volatile oil markets to ensure sustainable economic development. Due to the significant association between oil price and periods of recession, the researchers have revived the debates on the effects of oil price changes on the economic growth of GCC countries.

\subsection{Vulnerability of GCC Economies to Oil Price Volatility}

Following several years of strong performance, the disturbances in oil supplies and lower international demand for oil are expected to decrease the total growth of the GCC economies to about 2 percent over the year of 2013 (IMF report). According to the IMF forecast, the significant amount of fiscal surpluses of 4.25 per cent of GDP for the GCC region does not reflect the whole picture of their exposures. Many of the oil exporting countries in the region are not able to balance their budgets and do not have enough cushions against shocks. The amount of savings in many of these countries is not enough, which allows them to continue spending for future generations when the hydrocarbon reserves comes to an end. Therefore, without modifications, their governments will start using their savings for consumption by the year 2016 (Ahmad, 2013).

This statement by the IMF pinpoints two important facts; First, it acknowledges the importance of the international demand for oil to the economies of the GCC, and consequently, how vulnerable these economies are to international demand and hence, oil price volatility; Second, it demonstrates the significance of savings to sustainable economic growth of these countries.

GCC countries' heavy reliance on oil as their major source of income and revenue for the state have witnessed a substantial increase in government size over the last three decades, however, the price of oil fluctuated over the same period which lead to high volatility in the state budget and consequently governments, at different times, experienced fiscal and financial difficulties. Revenue volatility as a result of unexpected change in oil price creates a motive to save some of the resources for precautionary reasons. Saving more, in good times, will strengthen fiscal resilience to oil revenue shocks and hinder the deterioration in fiscal and external positions. These savings could be utilized to smooth consumption spending when resource inflows fall short. The optimal size of such a saving buffer would be maximized when revenue volatility is high and persistent.

\subsection{Savings Tend to Sustained Economic Growth}

Recent research examines the links between oil prices and macroeconomic variables, underscore the momentous influence of oil price fluctuations on economic activity in developed and in emerging markets (Balaz \& Londarev, 2006; Gronwald, 2008; Cologni \& Manera, 2008; Kilian, 2008; Lardic \& Mignon, 2006, 2008). The stipulated explanations for the relationship between oil price movements and macroeconomic performance has emerged from the observed linkage between oil price realizations and economic recession. (Rasche \& Tatom, 1977; Dagut, 1978; Darby, 1982; Lilien, 1982; Hamilton, 1983, 2009; Burbidge \& Harrison, 1984; Nasseh \& Elyasiani, 1984; Gisser \& Goodwin, 1986; Loungani, 1986). The literature, however, lacks studies that show the link between oil price change over a long period of time felt by net oil-exporting developing countries and their economic development.

On the other hand, there is a strong evidence in the literature indicating that countries with a high level of savings for an extended periods of time tend to have a large and sustained economic growth. This positive relationship is quantitatively strong and robust to different types of data employed (Attanasio et al., 2000; Banerjee \& Duflo, 2005). In an endogenous growth models, Singh (2009) argues that higher rates of saving can have permanent positive effect on economic growth. As savings increase, the accumulation of physical capital lead to a higher rate of progress of technological level which consequently would lead to an increase in economic growth (Lucas, 1988). Empirical research done by Alguacil et al. (2004) and Singh (2009), among others, offer verification to the hypothesis that savings growth boosts economic growth.

Furthermore, resource wealth can destabilize institutions by encouraging rent-seeking and corruption. This behavior risking misconduct and misuse of government savings and poor investment quality. The link between the institutional quality, resources and growth are all believe to play a role in explaining the natural resource curse (Sala-i-Martin \& Subramanian, 2003; Bhattacharyya \& Hodler, 2009). Resource-rich countries with stronger economic and political institutions manage to have better macroeconomic and growth performance (Arezki \& Brueckner, 2011).

Following the previous discussion, two main questions, predominantly pertinent to the GCC region are of interest to this research; First, can the level of savings smooth the impact of oil price shocks on economic growth? Second, does institutional quality play a significant role in shaping the relationship between the saving rate, oil price movements and economic growth? 
The rest of the paper is organized as follows. Section two briefly presents some stylized facts about the GCC countries. Section three develops our research hypotheses. Section four describes the data and methodology employed in the empirical research and defines the explanatory variables. Section five discusses the results, while the last section provides summary, conclusions and policy implications.

\subsection{Stylized Facts about the GCC}

GCC countries have much in common, in addition to their richness in hydrocarbon resources, they enjoy high financial surpluses and are relatively low populated countries. They, however, depend on oil to different degrees and are making efforts to diversify and liberalize their economies. For example, the UAE, Oman and Bahrain are less dependent on oil than Saudi Arabia, while Qatar depends more on gas.

The GCC countries are interesting for several reasons; First, recently the GCC countries have drawn mounting consideration. Since 2003, reflecting the period of high oil prices, GCC region became a hub of global economic development. They also play a big role as international investors, trade cohorts, and play a significant role in world market for energy. The GCC countries, as major exporters of oil in global markets for energy, share similar production structure concentrate mainly on a state-owned hydrocarbon sector and a non-oil sector which depends on services, imports and foreign workers. So their markets may be sensitive to changes in oil prices. Second, the GCC countries differ from those of other developed and emerging countries in that they are more sensitive to regional political events given their vicinity to countries with high political instability, in addition, they are highly segmented from the global markets.

Hydrocarbon resources play a crucial role in the development of the GCC countries. For example, the hydrocarbon sector constituted around 78 percent of their revenues in the year 2007. Their economies are dominated by the oil and gas sectors which accounts for 5 percent of global GDP, while it represents around 43 percent of the GDP of the GCC region. In addition, the GCC retains 36 percent of the world's oil reserves and 22 percent of the gas reserves. Altogether the region possesses a significant global natural resource wealth, especially given the GCC's limited share of the global population (GCC outlook, QNB, 2012), it, however, remains exposed to oil and gas price fluctuations. If the oil price remains consistently low it could potentially lead to fiscal constraints in some GCC countries, forcing them to cut back on spending or draw down from their Sovereign Wealth Funds to maintain expenditure levels in line with existing plans. According to the IMF report after many years of strong performance, the disturbances in oil supplies and lower international demand for oil were expected to decrease the aggregate growth of the GCC economies to about 2 percent over the year 2013 (IMF report, 2013).

Given the importance of oil revenues to the GCC region, it is plausible to find a strong association between national savings and oil revenues. The reduction in demand for oil or during times of lower oil prices eventually lead to a reduction in government revenues and consequently on saving rate. Although GCC oil reserves are quite large (the average reserves-to-production ratio for GCC oil was, on average, around 73 years, they will not remain for too long (Abi-Aad, 2009).

Table 1. Economic indicators of GCC economy

\begin{tabular}{cccc}
\hline Year/Indicators & GDP growth (annual \%) & GDP per capita growth (annual \%) & Gross savings (\% of GDP) \\
\hline $1980-1985$ & 1.37 & -3.77 & 42.84 \\
$1986-1990$ & 4.56 & 0.23 & 25.96 \\
$1991-1995$ & 6.3 & 1.28 & 5.16 \\
$1996-2000$ & 3.57 & 0.69 & 22.83 \\
$2001-2005$ & 6.14 & 1.16 & 32.81 \\
$2006-2011$ & 6.3 & -1.08 & 46.14 \\
\hline
\end{tabular}

Source: World Bank's World Development Indicators.

Table 1 shows the GDP average annual growth, per capita GDP, and saving trends from year 1980 to year 2011 averaged over five year periods. Although GDP annual growth rate increased on average since 1996, as a percent of the population, (average, year-on-year) per capita annual growth went down from 1.16 in the period 20012005 to -1.08 on the period 2006-20011 (average, year-on-year). So while revenues has produced by and large increase in GDP, the population growth has caused per capita growth to be negative. The average gross saving as a percent of GDP has also increased overtime since 1991.

The GDP of GCC countries have been consistently dominated by the revenue of both oil and gas sector (43 percent in year 2010) (IMF, National statistical authorities, QNB Group estimates). Many sectors, like 
construction, real estate, manufacturing, service, and hospitality, which represent around 39 percent of GDP have recently contributed significantly towards diversification of economic income.

\section{Method}

\subsection{Factors Affecting GCC Economic Growth}

This paper explores the effect of oil price changes, level of savings and institutional quality to determine the most robust factors that affect the growth in the GCC economies. The following variables are included in the study.

\subsubsection{Change in Oil Prices (Oil)}

GCC countries and their economies are highly vulnerable to oil price movements. The region remains exposed to oil and gas price fluctuations, which could potentially lead to monetary restraints in some of the GCC countries, driving them to reduce their spending to keep the level of spending consistent with existing plans (GCC Economic Insight, 2012).

A controversy still exists on the relationship between oil revenues and growth in oil exporting countries. Whether oil revenues is positively affecting economic growth, or it is a spell generates an important debate in the literature. Therefore, if oil rents is considered as a spell, we should expect a negative relationship between the change in oil prices and economic growth.

This paper looks at the growth rate in oil prices which reflects the unexpected changes in prices. A negative relationship is expected between changes in oil prices and the economic growth.

\subsubsection{Saving Rate (S)}

Previous literature demonstrate that higher saving rate increases the availability of funds for high investment, which consecutively accelerates the growth of the economy (Domer, 1946; Solow, 1956). Singh (2009), in his model, argues that, higher rates of saving can have permanent positive effect on economic growth. As savings increase, the accumulation of physical capital leads to a higher rate of progress of technological level which, consequently would lead to an increase in economic growth (Romer, 1986; Lucas, 1988). Contrary to these findings, studies of Jappelli and Pagano (1996), Sinha and Sinha (1998) propose that it is economic growth that elevates savings and not the savings as stimulants of economic growth (Harrod, 1939; Domer, 1946; Solow, 1956). Though the previous studies have shown mixed outcomes on the association between savings and economic growth, we reexamine the issue using data from GCC oil exporting countries.

Based on the above argument we hypothesize a positive relationship between saving rates and economic growth taking into account the possibility that the relationship could be bi-directional.

\subsubsection{Economic Globalization (KAOP)}

In a globalized world, trade and capital mobility between nations has turned out to be a significant source of economic development in many countries. The degree of openness is deemed crucial for economic growth. Studies examine the relationship between different proxies for globalization and economic growth find a significant and positive relationship connecting these variables in the recipient country (Dollar \& Kraay, 2001; Greenaway et al., 1999). Borensztein et al. (1998) demonstrate a positive effect of foreign direct investment on the level of human capital availability. Alfaro et al. (2004) shows that FDI is significantly and positively correlated with growth in countries with higher financial development. On the other hand, a study by Carkovic and Levine (2002) shows no effect of foreign direct investment on growth.

The Chinn-Ito index (KAOPEN) is an index assessing the degree of a country's economic globalization, which rates countries by their dependence on international trade, foreign investment, and foreign workers, plus any restrictions they place on the flow of goods and finance; higher numbers indicate greater economic globalization (see Dreher 2006, Dreher et al., 2008). Looking to the non-conclusive evidence shown by previous studies, our hypothesis tests the relationship between degrees of economic globalization and economic growth.

\subsubsection{Stock Market Capitalization (SMC)}

The total equity market capitalization of GCC stock markets' seven bourses grew at 13.2 percent from 20032011 to reach US\$693billion increasingly making their presence on the global equity market. However, the global financial crisis in late 2008, coupled with the bursting of the real estate bubble along with the sharp fall of oil prices during year 2008 affected their market performance (GCC Economic Insight, 2012). In such an environment, the corporate sector came under pressure, while the GCC region has seen few instances of corporate bankruptcies and very limited recourse as an unusual support for their financial sector (Source: Gulf 


\section{Base Database).}

The stock market-capitalization as a percent of GDP depicts the size of the stock market. It is measured as the average value of all listed stocks on domestic exchanges in a year as a percent of the GDP. We hypothesize a positive association between stock market capitalization and GDP growth.

\subsubsection{Institutional Quality and Government Stability (IQ)}

A weak political institutions can deter economic growth. We measure legal and Institutional quality by looking at 3 indices reported by the International Country Risk Guide (ICRG). We re-scaled the indices from 1 to 12, where good institutions take high values. We group Institutional Quality (IQ) indicators which covers the instruments linked to the general improvement of institutions and legal systems, calculated as an average of 3 indicators namely, corruption (Corr), law and order (LAO), Bureaucracy quality (BQ). We also group Stability (AVGST) by taking the average of the indicators which contains a measure related to Government Stability (GS) and Internal conflict (IC). These data series are obtained from ICRG database. The indices included in our study for (IQ) are:

1-Corruption - measures the level of all types of corruption such as discrimination, patronage, and any close relationships between political agencies and businesses.

2-Law and order (LAWO) measures the strength, impartiality and fairness of the legal system.

3-Bureaucracy quality: reflects the institutional strength and the attribute of the bureaucracy strength and expertise of the bureaucracy to regulate without extreme alteration in rules or any disruptions in the services of the government.

While the indicators related to (AVGST) are:

1-Government stability (GS) which measures the capability of the government to execute its programs and to stay in office.

2-Internal conflict (IC) which measures political violence within the country and its actual or expected impact on government power and control by concentrating on, for example, civil war, terrorism, political violence or civil disorder.

This research expects to find a positive effect of institutional and legal development, and stability on economic growth.

\subsubsection{Investment Profile (IP)}

The investment profile (INVPROF) is employed here in order to measure if the country is viewed risky for future investments. It assesses the attitude of the host country regarding foreign investment and measures risks to investment that are not part of other political and economic risks. It includes factors related, for example, to expropriation of assets, ability of foreign investors to repatriate profits, and contract feasibility. This measure is taken from ICRG. The index ranges from 0 to 12 (a higher score implies low risk to investment). However, we convert the index into a dummy variable for better interpretation of the results. The dummy variable employed has three groups: high risk group (if index lies between 0 and 4), medium risk group (if index lies between 4.1 and 8), and low risk group if (the index lies between 8.1 and 12). In this paper, we will use a low risk group as a reference group and, consequently, the dummy variable for low risk group takes the value of 0 , for medium risk group it will take the value of 1 and, finally, high risk group will take the value of 1 (Chinn \& Ito, 2006).

\subsubsection{Foreign Direct Investment (FDI)}

According to the IMF, Foreign direct investment (FDI) is defined as a long-term investment by a foreign company in an enterprise residing in a country other than that in which the foreign direct investor is based (ownership of 10 percent or more of voting stock). The data is taken from IMF "International Financial Statistics". The existing evidence on the relationship between FDI and economic growth is controversial. In theory, FDI is anticipated to assist the receiving country by shifting resources, helping in reducing unemployment, reducing the balance of payments deficit and transferring technology. Some researchers discussed effect of foreign direct investment in the technological progress of emerging economies. FDI improves the level of technological progress in the recipient country through a contagion effect from advanced technology and management practices (Findlay, 1978; Romer, 1990). Many emerging countries acknowledge the significance of FDI to their growth, start granting specific motivations in order to attract FDI. Therefore, FDI as a percent of GDP will be included as an independent variable in our analysis.

We hypothesize a positive relationship between FDI and economic growth of the GCC countries. 


\subsection{Data and the Empirical Model}

\subsubsection{The Data}

The data is taken from a different sources, mainly the World Bank's World Development Indicators, the International Financial Statistics of the IMF, and the International Country Risk Guide. The sample covers six countries comprising the GCC region (Saudi Arabia, United Arab Emirates, Qatar, Kuwait, Bahrain and Oman). The study is based on annual data and covers the period from 1980 to 2011. Our dependent variable is the growth in gross domestic product (GDP). The (GDP) is a basic measure of the economic performance of a country. It is expressed as the total market value of all final goods and services produced in the country in a given year. Output level and growth data in this paper is measured as the growth of real per capita GDP.

\subsubsection{Empirical Model}

This study uses time series cross sectional data (TSCS), which is more informative, gives more variability, less collinearity, more degrees of freedom, and provides estimates which are more efficient than either time series data or cross sectional analysis. It allows to study individual dynamics and provides information on the time-ordering of events. In addition, TSCS allows to control for individual unobserved heterogeneity.

First, we reexamine the long-term effect of oil price changes, savings and legal and institutional development on economic growth, controlling for different factors including globalization, foreign direct investment (FDI), and stock market capitalization. The model suggested is specified as:

$$
\Delta E G_{i t}=\alpha_{0}+\beta E G_{i, t-1}+\beta_{1} O i l_{i, t-1}+\beta_{2} S_{i, t-1}+\beta_{3} I Q_{i, t}+\rho Z_{i, t-1}+\varepsilon_{i, t}
$$

Where, EG is a measure of economic growth measured as the growth rate of per capita GDP; Oil is the change in oil prices; $\mathrm{S}$ is the level of gross domestic saving as a percent of GDP; IQ refers to a measure of legal or institutional quality; $\mathrm{Z}$ is a vector of economic control variables; $\mathrm{i}=1, \ldots, \mathrm{n}$ ( $\mathrm{n}-$ the number of countries); $\mathrm{t}$ $=1 \ldots \mathrm{T}(\mathrm{T}-$ the number of periods); $\alpha 0=$ intercept for country $\mathrm{i}$ which represents the individual (country-specific) effect on the dependent variable and is assumed to be constant over time-specific) effect on the dependent variable and is assumed to be constant over time.

This study will test the model using three methodologies; Fixed effect, variable effect and dynamic Time Series Cross Sectional (TSCS) regression models. To incorporate dynamic behavioral relationships of per capita GDP growth for each country, we first apply our data to both fixed effect and random effect dynamic panel models. These models take into account both intertemporal dynamic and individual differences and, consequently, provide better control for the effects of missing or unobserved variables which is common in such studies.

In the fixed effect model, equation becomes:

$$
\Delta E G_{i t}=\alpha_{i}+\beta E G_{i, t-1}+\beta_{1} O i l_{i, t-1}+\beta_{2} S_{i, t-1}+\beta_{3} I Q_{i, t}+\rho Z_{i, t-1}+\varepsilon_{i, t}
$$

Where $\alpha_{i}$ represents the unobserved effect which are country-specific. They are assumed to be different across country $\mathrm{i}$, while they are fixed over time. The error term $\varepsilon_{i, t}$ is expected to be independently, distributed across country i over time $t$ with a mean of zero and constant variance $\sigma 2$.

In the dynamic panel model, equation becomes:

$$
\Delta E G_{i t}=\alpha_{i}+\beta E G_{i, t-1}+\beta_{1} O i l_{i, t-1}+\beta_{2} S_{i, t-1}+\beta_{3} I Q_{i}, t+\rho Z_{i, t-1}+\gamma_{i, t}
$$

Where $\gamma_{i, t}=\alpha_{i}+u_{i t}$, and $\alpha$ are assumed to be independently, distributed across country $i$ with zero mean and variance $\sigma 2$ and uncorrelated with the independent variable. The error term is assumed to be independently, distributed across country $i$ and over time $t$ with mean zero and variance $\sigma 2$.

The fixed and the random effects panel data models take the country-specific heterogeneities of the countries under study into consideration. The fixed effect valuation takes in the country-specific effects as independent variables instead of allocating them to the error term, thus decreasing omitted variable bias. To determine the suitability of fixed effect specification or the pooled specification, we run an F-test. Under the null hypothesis, the F-test presumes a pooled model (i.e., confine the intercept to be the same across all observations). While the alternative hypothesis suggests that minimum one of the cross-sections is different. Consequently, rejection of the null hypothesis suggests the implementation of the least squares dummy variable (LSDV) model.

To choose between a fixed effect or random effect models, we will use of the Hausman (1978) test. If Hausman test preferred the Random Effects model, then we apply LM (Lagrange Multiplier) test to choose between 'Random Effects' and 'Pooled Classical Regression' models. In case F test suggests that country-specific effects are significantly different from each other, the optimal specification is given by the Fixed Effects model.

Our model includes the lag of per capita GDP growth as a regressor. Adding the lag of the dependent variable as 
a regressor lead to an increase in the correlation in the residuals. In addition, we assume that all our independent variables are exogenous, however, the joint endogeneity of some of our independent variables and the dependent variable leads to a misspecification problem in the econometric evaluation. Since some of our independent variables might be endogenous, these variables are correlated with the error term and, as a result, the standard OLS estimators might be biased and inconsistent. This might be the case with some of the independent variables included in our study. For example, Saving rate might affect economic growth and might be affected by it. Previous research on the relationship between saving and economic growth is inconclusive. In addition, FDI might boost the recipient country's capital stock, provides new technologies and increase the growth in GDP as well as GDP per capita (Busse \& Hefeker, 2005). To reduce these problems, we employ Arellano-Bond/Blundell-Bond estimator. The Arellano-Bond developed moment conditions using lagged-levels of the dependent variable and the determined variables with first-differences of the disturbances. However, if the autoregressive process is too persistent, then the lagged-levels are weak instruments (Arellano \& Bover, 1995; Blundell \& Bond, 1998). Arellano and Blundell suggests using extra moment conditions in which lagged changes of the dependent variable are orthogonal to levels of the disturbances. To get these additional moment conditions, the researchers presumed that the panel-level effect is unrelated to the first observable first-difference of the dependent variable.

The growth literature indicates the importance of averaging the data over a number of years and having many cross sectional units in order to eliminate cyclical fluctuations and to explore the long run relationship. In this study, since our data set is small, with just 6 countries if we average the data we will lose degrees of freedom. Since our data consist of yearly observations, taking the proper number of lags, we expect to capture the long run effect by taking the proper number of lags. We determine the lag by using F-tests of the null that an additional lag on the explanatory variables is jointly insignificant. This method exploits the dynamic properties of the data, and it is used to distinguish between both the short run and the long run effects.

\section{Empirical Results}

Our dependent variable is the GDP per capita growth (EG), while our independent variables are Oil price changes (Oil), Savings as a percent of GDP (S), and Institutional quality (IQ). The set of control variables used in this study include the foreign direct investment as a percent of GDP (FDI); market capitalization as a percent of GDP (SMC), KAOPEN index introduced by Chinn-Ito (KAOP), and investment profile dummy (IP). Since all our variables are adjusted for inflation, i.e. real, we do not include inflation rate to our regressors. Table 1 summarizes our variables, while table two shows the correlation between our variables. The table indicates that our data does not suffer from the problem with multi-collinearity. The maximum correlation of around 36 percent exists between economic growth and saving rates.

Table 2. Summary statistics

\begin{tabular}{llllll}
\hline Variable & Obs & Mean & Std. Dev. & Min & Max \\
\hline EG & 186 & 0.0228495 & 0.1580248 & -1 & 0.4 \\
S & 192 & 0.367588 & 0.2073413 & -0.67 & 0.9181928 \\
SMC & 192 & 55.57381 & 43.00001 & 5.489226 & 204.74 \\
Oil price & 192 & 49.30063 & 24.6376 & 17.01 & 105.84 \\
KAOP & 192 & 2.195833 & 0.4789986 & 1.120288 & 2.439009 \\
FDI & 192 & 1.961328 & 4.038654 & -13.60488 & 33.56602 \\
IQ & 192 & 8.690104 & 2.460485 & 0 & 12 \\
\hline
\end{tabular}

Note. EG (economic growth), S (savings), SMC (stock market capitalization), Oil (change in oil price), KAOP (is a measure of economic globalization), FDI (foreign direct investment), IQ (average institutional quality). 
Table 3. Correlation matrix

\begin{tabular}{lllllll}
\hline EG & S & SMC & Oil & KAOP & FDI & IQ \\
\hline EG & 1 & & & & & \\
S & 0.3573 & 1 & & & & \\
SMC & 0.2164 & 0.1999 & 1 & & & \\
Oil & 0.1826 & 0.3141 & 0.1545 & 1 & & \\
KAOP & -0.2088 & -0.0536 & 0.2754 & -0.2776 & 1 & \\
FDI & 0.0765 & 0.0442 & 0.3471 & 0.0649 & -0.045 & 1 \\
IQ & 0.2962 & -0.0121 & 0.1909 & -0.3086 & 0.2254 & \\
\hline
\end{tabular}

Note. EG(economic growth), S (savings), SMC(stock market capitalization), Oil (change in oil price), KAOP(is a measure of economic globalization), FDI(foreign direct investment), IQ(average institutional quality).

First, we ran the fixed effect and the random effect regression. Our test results show that the probability of Chi Square of 0.329 was larger than Alpha 5\% so we had accepted the random effect model as it fits our data better than fixed effect model. Therefore, we just show the results of random effect model in Table 3. The results of Lagrange multiplier shows that the Probability of Chi Square is 0,0000 smaller than Alpha 5\%, which is another indication to reject the null hypothesis and accept the Random Effect Model to be the best model (chosen model) for this study. The model is significant at 5 percent level as shown by the value of chi square. Table three shows that the lag of the change in per capita GDP is significant and positively related to the current change in per capita GDP. In addition, financial stability is considered important in determining the growth of the economy. One interesting result is a nonlinear relationship between the level of savings and the growth in per capita GDP. At low rates of savings, any increase in savings leads to an increase in the growth of GDP, however, at higher level of savings, the relationship becomes negative and significant. This indicates that the relationship between savings and economic growth is concave.

Oil price changes are shown to be significant and positively related to economic growth. This is consistent with the recent work which examines the link between oil prices and macroeconomic variables. This work has emphasized the considerable effects of oil price fluctuations on economic activity in both developed and in emerging economies (Cunado \& Perez de Garcia, 2005; Balaz \& Londarev, 2006; Gronwald, 2008; Cologni \& Manera, 2008; Kilian, 2008; Lardic \& Mignon, 2006, 2008). The findings also indicate that the other GCC economies are highly linked to oil prices and are heavily reliant on oil exports and are less affected by domestic circumstances.

As the GCC countries become wealthier, the government is set under pressures to let people participate in the oil proceeds, and an instant distribution of the oil revenues increases during the high demand for oil from the international market. With high liquidity in the hand of the people, the amount of both savings and consumption increase and consequently the economy is expected to grow further to meet high demand for consumption. With the increase in oil revenues further, people become richer and when the total amount of savings from oil revenues are too high, a large percentage of these savings could be saved abroad since the volume of saving could surpass the absorption capacity of local production and investments, therefore, the economy might slow down. In particular, with high liquidity, policy makers would invest in foreign financial assets for future generations, when absorptive capacity constraints make it impossible to invest faster at home.

Table 4. Time series cross sectional random effect regression results

\begin{tabular}{ll}
\hline EG & Coef. Std. \\
\hline EGt-1 & $.1888624(0.010)^{*}$ \\
S & $.3133905(0.000)^{*}$ \\
SMC & $.0001736(0.418)$ \\
Oil & $.0490737(0.046)^{*}$ \\
KAOP & $-.0083146(0.300)$ \\
avgst & $.0032513(.329)$ \\
Ssqr & $-.235919(0.012)^{*}$ \\
IQ & $.0094046(0.092)^{* *}$ \\
IP & $-.007274(0.191)$ \\
FDIt-1 & $.0026(0.856)$ \\
\hline
\end{tabular}




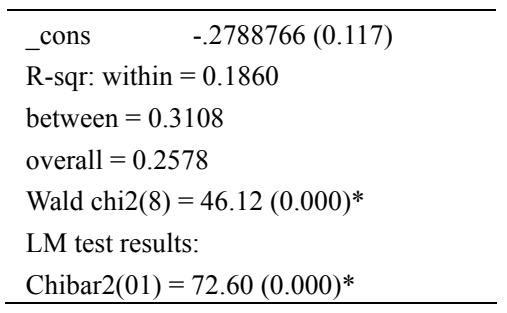

The output in Table 4 presents strong evidence supporting the null hypothesis of zero autocorrelation in the first-differenced errors at order 1. Serial correlation in the first-differenced errors at an order higher than 1 suggests that the moment conditions used by xtabond are not valid. The output presents no significant evidence of serial correlation in the first-differenced errors at orders 1 and 2 for all the models in the three panels. In addition, Sargan test is insignificant, which implies that our model is well specified.

Table 4 reports the results of Arellano and Blundell test. We run our tests for one-step and two-step GMM estimators. The two models are asymptotically equivalent for the first-differenced estimator. Therefore, we only report the results for the two-step GMM estimators. Table 4 Panel A shows the effect of the lag in economic growth, savings, the change in oil prices and FDI. Results show the level of savings and oil price change affect positively and significantly the economic growth in the GCC market. To see the effect of the institutional quality, investment freedom, trade openness, and economic stability, panel B of Table 4 added these factors to our regression. Our results indicate that the amount of savings and oil price change are positively related to economic growth at a 5 percent significance level. In this model stock market capitalization and FDI become significant factors affecting the growth in per capita GDP. In the last panel (C), we added the square of the singings. The coefficient of the square of savings is significant, however, negatively related to economic growth. Therefore, results show that the relationship between saving rates and economic growth is not linear, but rather is concave. As we mentioned previously, regardless of the model used, still we found the same results. This result indicates that, as the countries revenues and surpluses increase significantly (at higher levels in revenues and savings), the role of savings in economic growth diminishes. This might due to the lack of absorption capacity of the markets that are not enough investment alternatives available, therefore capital flows to foreign countries searching for investments with higher returns. Oil price changes affect the growth significantly. Thus, after controlling for different factors, oil price changes explain the variability in the economic growth of the GCC countries.

At a lower level of income and savings, causality runs from saving to growth which is consistent with the general view that high saving produces high growth via the link from saving to capital and capital output. At higher saving levels, the negative correlation is consistent with the optimal growth model assuming consumers have increased information about income growth. The reason is given by Campbell (1987), who suggests that the consumption should decrease before any reduction in income if the decline in income were expected (i.e human wealth effect on consumption). In addition, this result could also be supplied by a Keynesian model with myopic consumers whose consumption function was subject to stochastic shocks. A positive shock to saving would decrease total demand and, therefore, reduce income in the following quarter.

Table 5. Results of arellano and blondell one-step system GMM results

\begin{tabular}{llll}
\hline EG & Panel A & Panel B & Panel C \\
\hline EGt-1 & -0.0621093 & -0.0859 & -0.1078 \\
& $(-0.44)$ & $(-0.215)$ & $(-0.166)$ \\
S & 0.1533333 & 0.14983 & 0.2996 \\
& $(0.000)^{*}$ & $(0.000)^{*}$ & $(0.000)^{*}$ \\
SMC & 0.0000467 & 0.000224 & 0.0003 \\
& -0.711 & $(.050)^{*}$ & $(.018)^{*}$ \\
Oil & 0.004187 & 0.00499 & 0.0052 \\
& $(0.000)^{*}$ & $(0.000)^{*}$ & $(0.000)^{*}$ \\
FDI & -0.001808 & 0.0044 & 0.0037 \\
& $(-0.149)$ & $(.07)^{* *}$ & $(-0.28)$ \\
KAOP & & -0.0258335 & -0.0253 \\
& & $(0.000)^{*}$ & $(.017)^{*}$ \\
\hline
\end{tabular}




\begin{tabular}{llll}
\hline IQ & & 0.0112363 & 0.0133 \\
& & 0.297 & 0.31 \\
IP & & -0.0009391 & -0.0012 \\
& & $(0.066)^{*}$ & $(.043)^{*}$ \\
Avgst & & 0.0038688 & -0.0004 \\
& & 0.531 & 0.936 \\
Ssqr & & & -0.256 \\
& & & $(0.000)^{*}$ \\
cons & -0.2115289 & -0.248 & -0.2462 \\
& $(0.000)^{*}$ & $(.017)^{*}$ & $(.007)^{*}$ \\
Wald chi2 & 138.44 & 138.44 & 484.3 \\
Prob > chi2 & $\left(0.000^{*}\right)$ & $(0.000)^{*}$ & $(0.000)^{*}$ \\
Sargan test Chi2 & 18.9518 & 15.31387 & 16.622 \\
& $(0.089)^{* *}$ & 0.224 & 0.1644 \\
AR(1) & -1.5783 & -1.41 & -1.455 \\
& 0.1145 & $0.1585)$ & 0.1458 \\
AR(2) & -1.0008 & -0.79465 & -0.006 \\
& $(0.3169$ & $(0.4268$ & 0.995 \\
\hline
\end{tabular}

Standard errors in parentheses: *significant at 5 percent, ** significant at 10 percent level. Where: EG (economic growth), $\mathrm{S}$ (savings as a percent of GDP), SMC (stock market capitalization as a percent of GDP), Oil (change in oil price), KAOP (measure of globalization), FDI (foreign direct investment as a percent of GDP), IP (investment profile), IQ (average legal and institutional quality), Sqr (saving as a percent of GDP square).

\section{Discussion}

This research focuses on the simultaneous links between oil price changes, national savings, legal and institutional development, and economic growth in the GCC countries over the period 1980 to 2011. The study period chosen includes oil shocks and adverse events such as the Iraqi invasion of Kuwait, as well as, the financial crisis. We use two different econometric techniques and control for the endogeneity problem, which prevails in this kind of studies. Our study includes six GCC countries namely, Bahrain, Kuwait, Oman, Qatar, Saudi Arabia and the United Arab Emirates.

The empirical results show, regardless of the model used, that the relationship between saving rates and economic growth is not linear, but rather is concave. At higher saving levels, the negative correlation is consistent with the optimal growth model if consumers have advance knowledge about income growth. After controlling for different factors, we find that oil price changes could explain the variability in the economic growth of the GCC countries. The degree of openness is considered necessary indicator which boosts economic growth, while institutional quality is insignificantly related to economic growth.

The researchers recommend that these countries should increase their savings, which should be channeled wisely into investments that guarantee a high level of economic diversification. In addition, in order to make use of the increased national savings, and to increase the absorption capacity, the GCC countries should encourage private investments which eventually would help improve the long run performance of their economies especially when oil and gas come to an end.

\section{References}

Abi-Aad, N. (2009). Energy in the Mediterranean and the gulf: Opportunities for synergies document IAI 0935. Istituto Affari Internazionali, December.

Ahmad, M. (2013). Is the GCC spending its way into a fiscal deficit? Published November 13th, via SyndiGat. info.

Alguacil, M., Cuadros, A., \& Orts, V. (2002). Foreign direct investment, exports and domestic performance in Mexico: A causality analysis. Economics Letters, 77, 371-376. http://dx.doi.org/10.1016/S0165-1765(02)00150-7

Alguacil, M., Cuadros, A., \& Orts, V. (2004). Does saving really matter for growth? Mexico (1970-2000). Journal of International Development, 16(2), 281-290. http://dx.doi.org/10.1002/jid.1075

Arellano, M., \& Bover, O. (1995). Another look at the instrumental variable estimation of error-components 
models. Journal of Econometrics, 68, 29-52. http://dx.doi.org/10.1016/0304-4076(94)01642-D

Arezki, R. K., Deininger, \& Selod, H. (2011). Interest in large-scale land acquisition for agribusiness investment: Extent and determinants and the global land grab. Policy Research Working Paper, World Bank, Washington, DC.

Attanasio, O. P., Picci, L., \& Scorcu, A. (2000). Saving, growth and investment: A macroeconomic analysis using panel data of countries. Review of Economics and Statistics, 82(2), 182-211. http://dx.doi.org/10.1162/003465300558731

Balaz, P., \& Londarev, A. (2006). Oil and its position in the process of globalization of the world economy. Politicka Ekonomie, 54(4), 508-528.

Banerjee, A. V., \& Duflo, E. (2004, December). Growth theory through the lens of development economics. MIT Department of Economics Working Paper No. 05-01. http://dx.doi.org/10.2139/ssrn.651483

Banerjee, A., Dolado, J., \& Mestre, R. (1998). Error-correction mechanism tests for cointegration in a single-equation framework. Journal of Time Series Analysis, 19, 267-283. http://dx.doi.org/10.1111/1467-9892.00091

Blundell, R., \& Bond, S. (1998). Initial conditions and moment restrictions in dynamic panel data models. Journal of Econometrics, 87(1), 115-143. http://dx.doi.org/10.1016/S0304-4076(98)00009-8

Borensztein, E. J., De Gregorio, J., \& Lee, J. W. (1998). How does foreign direct investment affect economic $\begin{array}{lllll}\text { growth? Journal of International } & \text { Economics, }\end{array}$ http://dx.doi.org/10.1016/S0022-1996(97)00033-0.

Burbidge, J., \& Harrison, A. (1984). Testing for the effects of oil-price rises using vector Autoregressions. International Economic Review, 25, 459-484. http://dx.doi.org/10.2307/2526209

Busse, C. H. (2005). Political risk, institutions and foreign direct investment: HWWA Discussion Paper, 315 Hamburgisches Welt-Wirtschafts-Archiv(HWWA). Hamburg Institute of International Economics.

Chinn, M., \& Hiro, I. (2006). What matters for financial development? Capital controls, institutions, and $\begin{array}{lllll}\text { interactions. Journal of Development } & \text { Economics, }\end{array}$ http://dx.doi.org/10.1016/j.jdeveco.2005.05.010

Cologni, A., \& Manera, M. (2008). Oil prices, inflation and interest rates in a structural cointegrated VAR model for the G-7 countries. Energy Economics, 30(3), 856-88. http://dx.doi.org/10.1016/j.eneco.2006.11.001

Cunado, J., \& Perez de Garcia, F. (2005). Oil prices, economic activity and inflation: Evidence for some Asian countries. Quarterly Review of Economics and Finance, 45(1), 65-83. http://dx.doi.org/10.1016/j.qref.2004.02.003

Dagut, M. B. (1978). The economic effect of the oil crisis on South Africa. South African Journal of Economics, 46(1), 23-35. http://dx.doi.org/10.1111/j.1813-6982.1978.tb00543.x

Darby, M. (1982). The price of oil and world inflation and recession. American Economic Review, 72, 738-751.

Dollar, D. (1999). The transformation of Vietnam's economy: Sustaining growth in the 21st century. In Market Reform in Vietnam. In J. Litvack \& D. Rondinelli (Eds.), Building Institutions for Development. London: Quorum Books.

Dollar, D., \& Kraay, A. (2001). Trade, growth, and poverty. World Bank, Development Research Group, Macroeconomics and Growth.

Domer, E. D. (1946). Capital expansion, rate of growth, and employment. Econometrica, 14, 137-147. http://dx.doi.org/10.2307/1905364

Dreher, A. (2006). Does globalization affect growth? Empirical evidence from a new index. Applied Economics, 38(10), 1091-1110. http://dx.doi.org/10.1080/00036840500392078

Findlay, R. (1978). Relative backwardness, direct foreign investment, and the transfer of technology: A simple dynamic model. Quarterly Journal of Economics, 92, 1-16. http://dx.doi.org/10.2307/1885996

Gavin, M., Hausmann, R., \& Talvi, E. (1997). Saving Behavior in Latin America: Overview and Policy Issues. IDB Working Paper No. 286. http://dx.doi.org/10.2139/ssrn.1815974

Gisser, M., \& Goodwin, T. H. (1986). Crude oil and the macroeconomy: Tests of some popular notions. Journal of Money, Credit and Banking, 18, 95-103. http://dx.doi.org/10.2307/1992323 
Greenaway, D., Wyn, M., \& Peter, W. (1999). Exports, export composition and growth. Journal of International Trade \& Economic Development, 8(1), 41-51. http://dx.doi.org/10.1080/09638199900000004

Gronwald, M. (2008). Large oil shocks and the US economy: Infrequent incidents with large effects. Energy Journal, 29(1), 151-171. http://dx.doi.org/10.5547/ISSN0195-6574-EJ-Vol29-No1-7

Hamilton, J. D. (2009). Understanding crude oil prices. Energy Journal, 30(2), 179-206. http://dx.doi.org/10.5547/ISSN0195-6574-EJ-Vol30-No2-9

Handbook of Economic Growth. (2012). Vol. 1a GCC outlook, QNB. Retrieved from http://www.qnb.com.qa/cs/Satellite?blobcol=urldata\&blobheader=application\%2Fpdf\&blobkey=id\&blobta ble $=$ MungoBlobs\&blobwhere $=1355478498222 \&$ ssbinary $=$ true

Hausman, J. (1978). Specification tests in econometrics. Econometrica, 46, 1251-1271. http://dx.doi.org/10.2307/1913827

IMF Report. (2013). World Economic Outlook (WEO). Retrieved from http://www.imf.org/external/pubs/ft/weo/2013/02/index.htm

International Financial Statistics of the IMF and the International Country Risk Guide. Retrieved from http://www.prsgroup.com/PDFS/icrgmethodology.pdf

Jappelli, T., \& Pagano, M. (1994). Saving, growth, and liquidity constraints. Quarterly Journal of Economics, 109(1), 83-109. http://dx.doi.org/10.2307/2118429

Jappelli, T., \& Pagano, M. (1996). The determinants of saving: Lessons from Italy. Paper presented at the Inter-America Development Bank Conference on Determinants of Domestic Saving in Latin America, Bogota, Columbia.

Kilian, L. (2008). Exogenous oil supply shocks: How big are they and how much do they matter for the US economy? Review of Economics and Statistics, 90(2), 216-240. http://dx.doi.org/10.1162/rest.90.2.216

Lardic, S., \& Mignon, V. (2008). Oil prices and economic activity: An asymmetric cointegration approach. Energy Economics, 30(3), 847-855. http://dx.doi.org/10.1016/j.eneco.2006.10.010

Lilien, D. (1982). Sectoral shifts and cyclical unemployment. Journal of Political Economy, 90(4), 777-793. http://dx.doi.org/10.1086/261088

Loungani, P. (1986). Oil price shocks and the dispersion hypothesis. Review of Economics and Statistics, 68(3), 536-539. http://dx.doi.org/10.2307/1926035

Lucas, R. E. (1988). On the mechanics of economic development. Journal of Monetary Economics, 22(1), 3-42. http://dx.doi.org/10.1016/0304-3932(88)90168-7

Nasseh, A. R., \& Elyasiani, E. (1984). Energy price shocks in the 1970s; impact on industrialized countries. Energy Economics, 6(4), 231-244. http://dx.doi.org/10.1016/0140-9883(84)90002-1

Rasche, R. H., \& Tatom, J. A. (1981). Energy price shocks, aggregate supply, and monetary policy: The theory and international evidence. In K. Brunner \& A. H. Meltzer (Eds.), Carnegie-Rochester Conference Series on Public Policy. North Holland: Amsterdam.

Rodrik, D. (1998). Who needs capital-account convertibility? In S. Fischer (Eds.), Should the IMF pursue capital account convertibility. Princeton, New Jersey: International Finance Section.

Rogoff, K. (1999). International institutions for reducing global financial instability. Journal of Economic Perspectives, 13(4), 21-42. http://dx.doi.org/10.1257/jep.13.4.21

Romer, P. (1990). Endogenous technological change. Journal of Political Economy, 98, 71-102. http://dx.doi.org/10.1086/261725

Romer, P. M. (1986). Increasing returns and long run growth. J. Polit. Econ., 94, 1002-1037. http://dx.doi.org/10.1086/261420

Sala-i-Martin, X., \& Subramanian, A. (2003). Addressing the natural resource curse: An illustration from Nigeria. IMF Working Paper, 03, 139. Retrieved from https://www.imf.org/external/pubs/ft/wp/2003/wp03139.pdf

Saltz, I. S. (1999). An examination of the causal relationship between savings and growth in the third world. Journal of Economics and Finance, 23(1), 90-98. http://dx.doi.org/10.1007/BF02752690

Sambit, B., \& Roland, H. (2010). Natural resources, democracy and corruption. European Economic Review, 
54(4), 608-621. http://dx.doi.org/10.1016/j.euroecorev.2009.10.004

Singh, T. (2009). Does domestic saving cause economic growth? A time-series evidence from India. Journal of Policy Modeling.

Sinha, D., \& Sinha, T. (1998). Cart before the horse? The saving-growth nexus in Mexico. Economics Letters, 61(1), 43-47. http://dx.doi.org/10.1016/S0165-1765(98)00144-X

Solow, R. M. (1956). A contribution to the theory of economic growth. Quarterly Journal of Economics, 70, 6594. http://dx.doi.org/10.2307/1884513

Summers, L. H. (2000). International financial crises: Causes, prevention, and cures. American Economic Review, 90(2), 1-16. http://dx.doi.org/10.1257/aer.90.2.1

World Development Indicators. (2013). The World Bank's. Retrieved from http://data.worldbank.org/data-catalog/world-development-indicators

\section{Copyrights}

Copyright for this article is retained by the author(s), with first publication rights granted to the journal.

This is an open-access article distributed under the terms and conditions of the Creative Commons Attribution license (http://creativecommons.org/licenses/by/3.0/). 